\title{
Determinants of China's Energy Imports: An Empirical Analysis *
}

Xingjun Zhao, Department of International Economics and Trade, Nankai University, PR China and Yanrui Wu, Business School, University of Western Australia ${ }^{\dagger}$

(forthcoming in Energy Policy)

* We thank Nicolaas Groenewold, an anonymous referee and participants at the 18th annual conference of ACESA, Emerging China: Internal Challenges and Global Implications, for helpful comments. The draft of the paper was completed while the first author was visiting the Business School of University of Western Australia. His visit was funded by the Australia-China Council, DFAT, Canberra.

†Corresponding author (yanrui.wu@uwa.edu.au). 


\title{
Determinants of China's Energy Imports: An Empirical Analysis
}

\begin{abstract}
$\underline{\text { Abstract }}$
Sustained economic growth in China has triggered a surge of energy imports, especially oil imports. This paper investigates the determinants of China's energy import demand by using cointegraiton and VECM techniques. The findings suggest that, in the long run, growth of industrial production and expansion of transport sectors affect China's oil imports, while domestic energy output has a substitution effect. Thus, as the Chinese economy industrializes and the automotive sector expands, China's oil imports are likely to increase. Though China's domestic oil production has a substitution effect on imports, its growth is limited due to scarce domestic reserve and high exploration costs. It is anticipated that China will be more dependent on overseas oil supply regardless of the world oil price.
\end{abstract}

Key words: Energy consumption, energy imports, China and VECM 


\section{Introduction}

In the past twenty-seven years, China has undertaken market-oriented economic reforms and achieved an average annual growth rate of $9.62 \% .^{1}$ The expansion of economic activities and growth of household expenditure have led to a surge in demand for primary energy consumption, which gradually cannot be satisfied by domestic production since the 1990s. The gap between domestic energy production and consumption has been increasing (Figure 1). As a result, China has become a net importer of crude oil since 1993 and in 2003 surpassed Japan as the world's second-largest oil importer (only behind the United States).

$<$ insert Figure 1 here $>$

The development of China's energy market in the past decades can be divided into three stages. The first stage covers the period from 1953 to the early 1970s during which China's energy consumption grew relatively slowly and kept pace with domestic production. The second period falls between 1973 and 1992, during which total output of energy production exceeded total consumption with a moderate annual growth rate. The third stage begins in the early 1990s. Since then, China's energy consumption has overtaken domestic production and hence the country has become a net energy importer. Energy consumption has expanded even faster in recent years.

Another important feature of China's energy market is its unbalanced product mix which is dominated by coal (with a share of $68.7 \%$ in total energy usage in 2005).

\footnotetext{
${ }^{1}$ This figure is calculated using SSB data (National Bureau of Statistics various issues).
} 
Clean energy such as natural gas and hydroelectricity plays a relative small role with market shares of $2.8 \%$ and $7.3 \%$ in 2005 , respectively (National Bureau of Statistics, 2006). With the growing environmental concern among the Chinese people, there is great pressure for China's energy industries and policy makers to change the energy structure and resort to cleaner energy sources (i.e., natural gas and hydroelectricity) as well as renewable resources (i.e., solar, geothermal and wind energies).

In order to fill the gap between domestic energy production and consumption and maintain high economic growth (the Sixteenth National Congress set a target of four-fold growth between 2000 and 2020, implying a rate of growth of 7\% per annum) without further environmental damage, China has adopted the strategy of diversifying the sources and composition of energy. China has now established extensive cooperation relationships with many energy exporting countries such as Russia, the Gulf States, Canada, Azerbaijan, Kazakhstan, Venezuela, Sudan, Indonesia, Iraq, and Iran. According to IEA (2005), China now imports $40 \%$ of its oil, of which some $60 \%$ comes from the Middle East. The same source suggests that China's total oil demand would increase from 6.4 million barrels per day (mb/d) in 2004 to over $13 \mathrm{mb} / \mathrm{d}$ in 2030, which implies that a large proportion of China's oil demand will have to be met by imports and the country's net oil imports would rise from $2.3 \mathrm{mb} / \mathrm{d}$ in 2004 to 4.5 $\mathrm{mb} / \mathrm{d}$ in 2010 and $10.5 \mathrm{mb} / \mathrm{d}$ in 2030. This would raise China's dependency on imported oil to $75 \%$ within the next 25 years and hence would have important implications for the world oil market. 
The objective of this paper is to examine the factors that affect and determine China's demand for energy imports, which is critical to the understanding of China's energy supply and demand as well as energy import strategy in the country. For this purpose, an econometric model is proposed and applied to Chinese quarterly data from 1995:Q1 to 2006:Q1. The findings are then employed to draw implications for China's energy trade.

The rest of the paper is organized as follows. Section 2 presents a brief review of the relevant studies. Section 3 discusses the main factors affecting China's energy import demand. The econometric method and model specification are introduced in Section 4. This is followed by description of data issues and interpretation of the empirical findings in Section 5. Finally, Section 6 concludes the paper.

\section{Literature review}

In the literature, there are a variety of studies on China's energy issues. Some researchers argue that economic growth and key macro-variables are the determinants of energy consumption and hence apply these variables to project energy consumption (Hirschhausen and Andres 2000; Li 2003; Crompton and Wu 2004; Skeer and Wang 2007). Others examine the determinants of energy demand before the forecasts are conducted (Chan and Lee 1996; Wei 2002; Zou and Chau 2006; Skeer and Wang 2006). For example, Chan and Lee (1997) forecasted the demand for coal in China by 
using Engel-Granger's error correction model and Hendry's general to special approach. Keii (2000) predicted that China's demand for coal would reach 1.3 billion tones in 2010, accounting for about $65 \%$ of China's primary energy, and coal consumption in China would grow at a more modest annual rate of $2 \%$ in the first decade of $21^{\text {st }}$ century. Hirschhausen and Andres (2000) examined the outlook for electricity demand in China until 2010 at a national, sectoral and regional level, and projected gross electricity demand of 1500 terawatt-hour (Twh) in 2010. Han et al. (2000) and Zhou (1999) argued that growth in natural gas demand would be much greater in the first decade of the $21^{\text {st }}$ century. The implied annual rate of growth in natural gas consumption in the first two decades of the $21^{\text {st }}$ century is about $9 \%$ and 11\% according to Han et al. (2000) and Zhou (1999), respectively. Li (2003) simulated China's economy, energy and environment in an integrated econometric model and projected that economic growth rate in China would be around $7 \%$ annually in the coming 30 years and would result in unsolvable difficulties for energy security, air protection, and $\mathrm{CO}_{2}$ emission reductions. Crompton and $\mathrm{Wu}$ (2004) employed a Baysian vector autoregressive (BVAR) model to project China's primary energy demand up to 2010. Their results suggest that total energy consumption should increase to 2173 million tons coal-equivalent (MtCE) in 2010 with an annual growth rate of $3.8 \%$, which is slightly smaller than the average rate in the past decade. Their projection also indicates that the share of coal and natural gas in primary energy consumption will be around $65 \%$ and 3.4\%, respectively. Moreover, oil imports will reach 120-182 million tones by 2010, accounting for a half of China's total oil 
consumption. Skeer and Wang (2007) examined the trends in China's freight and passenger traffic sector and projected the sector's demand for oil in 2020 to be in the range from 191 to 363 million tons oil-equivalent (MtOE). They also found that the new demand from China's transport sector would likely push up world oil prices in 2020 with a range of $1-10 \%$ under different assumptions.

Chan and Lee (1996) used cointegration and vector error correction model (VECM) techniques to analyze China's energy consumption behavior, suggesting that energy price, income and the share of heavy industry output in national income were significant factors affecting energy consumption. Wei (2002) examined the long-run relationship between total energy consumption and some main economic factors such as energy price, income and share of heavy industry in GDP and found that energy consumption and main variables are cointegrated. Wolde-Rufael (2004) investigated the causal relationship between various kinds of industrial energy consumption and real GDP in Shanghai for 1952-1999. The empirical evidence suggested that there was a uni-directional Granger causality running from coal, coke, electricity and total energy consumption to real GDP, except oil consumption. Zou and Chau (2006) examined the relationship between oil consumption and economic growth in China using cointegration and ECM models and suggested that oil consumption had a great effect on economic growth. Zhang (2003) investigated the change in energy consumption in China's industrial sector and showed that the drop of real energy intensity contributed to the decline in industrial energy use in the 1990s. Skeer and 
Wang (2006) studied the possibility of substitution of natural gas for coal in China's power sector and suggested that under average cost conditions today, gas-fired power is roughly two-thirds more costly than coal fired power.

In summary, two general conclusions can be drawn from the current studies. First, economic growth is the most important factor in determining China's energy consumption. With sustained growth, China's energy consumption will grow dramatically in the coming two decades and domestic production cannot meet the demand because of the constrained production capacity or requirement for vast investment in energy transport facilities. Second, although China aims to reduce coal consumption and increase the share of clean energy (i.e., natural gas and renewable energy), China's energy consumption structure will change slowly. The share of coal will decrease to around $65 \%$ and that of natural gas will increase from $3 \%$ at present to about 7\% in 2010 (Crompton and Wu 2004; IEA 2005). However, current studies have mainly focused on China's aggregate energy supply and demand and the determinants of China's demand for energy imports are rarely considered. This paper adds to the literature by examining the determinants of China's energy imports and using the findings to draw implications for China's energy trade.

\section{Factors affecting China's oil imports}

With rapid economic growth and improvement of the standard of living, China is confronted with energy shortage and has to quest for energy security world-wide. So 
far China's energy imports are mainly crude oil and petroleum products. Thus, this section discusses the major determinants of China's oil imports including the price of crude oil, domestic energy production, industrial output and total traffic volume.

\subsection{The price of crude oil}

Crude oil price is an important variable influencing oil imports. Economic theories suggest that when energy price rises, the quantity of energy demanded should fall, holding all other factors constant. But, in empirical studies, energy demand is considered to be inelastic with respect to price, especially in the short-run (Dahl and Sterner 1991; Bernstein and Griffin 2005). This may be due to the absence of alternative choices or substitute fuels for the households and industry sectors. Even when the price of energy goes up dramatically, people continue to consume gas and electricity in their everyday life, and factories cannot reduce energy use so as to avoid production interruptions in the short run. As a result, energy demand may not change significantly following a price change, especially in the short-run. In addition, international oil price, which changes constantly in response to the global shocks in both supply and demand sides, can be seen as a proxy of international market condition that China faces.

As to energy demand by the industrial sectors, the relative price between inputs (i.e., energy) and outputs (industrial products) may be more important than the international energy price in absolute terms. If the prices of industrial products and 
energy products change by the same proportion, the quantity of energy demand may not change. Since most primary energy products, especially crude oil, are used as production factors in the industrial sector, to examine the response of import demand to changes in real energy price, the price of oil in relative terms (i.e. the ratio of crude oil price to industrial product price index) is employed in the empirical analysis. ${ }^{2}$

\subsection{Domestic energy production}

Domestic energy output is considered as another important factor affecting China's energy imports. Although China is the second largest energy producer in the world after the US, the country is poorly endowed on a per capita basis. In addition, China's energy production is dominated by coal with an output share over 70 per cent (Table 1 ), which is very similar to the consumption pattern. This kind of structure is due to China's rich coal reserve and relatively low production cost. The shares of natural gas and hydroelectricity are relatively constant around $3 \%$ and $8 \%$, respectively. In 2004 , China's total energy output was 1.846 billion tones of coal equivalent (BtCE), which was insufficient to meet the total consumption of 1.97 BtCE. In the same year, the country produced 174.5 million tones of crude oil, which was about $4.5 \%$ of world output, and consumed 308.6 million tones which amounted to about 8.2 per cent of world oil consumption. ${ }^{3}$ As a result, China's oil imports reached 122.7 million tones in 2004 (Table 2). The apparent gap between oil supply and demand is expected to widen in the coming two decades due to China's limited capacity of oil production.

\footnotetext{
${ }^{2}$ Industrial consumption of energy accounted for about $70 \%$ of China's total energy consumption in 2005 according to the National Bureau of Statistics (2006).

${ }^{3}$ BP (2005). BP Statistical review of world energy, June, 2005, p4.
} 
China's major oil fields accounting for about 90 per cent of total crude oil production are located in eastern China and their production capacity has peaked and is declining. New proved oil resources are in western China and too expensive to be explored. In addition, the shortage of energy transport infrastructure restrains China's eastern energy users from access to the country's western energy resources.

$<$ Table 1 is near hear. $>$

$<$ Table 2 is about hear. $>$

Furthermore, China's gas production is very small due to a limited reserve. At the end of 2004, the proved reserve of natural gas in China was 2.23 trillion cubic meters, which was only $1.2 \%$ of world's total reserve. ${ }^{4}$ To increase production capacity and consumption of natural gas, China has embarked on a major expansion of gas infrastructure. The West-East pipeline linking Shanghai and Xingjiang is now operating commercially and several LNG receiving terminals are also under construction or consideration. $^{5}$

\subsection{Industrial output}

Strong economic growth, especially in industrial production, continues to boost China's total primary energy consumption. Although economic growth seems to be the most important factor affecting energy demand, industrial production rather than gross domestic product (GDP) is chosen as the indictor of growth for two reasons. First, the industry sector amounted to about 70 per cent of China's total primary

\footnotetext{
${ }_{5}^{4}$ BP (2005). BP Statistical review of world energy, June, 2005, p20.

${ }^{5}$ IEA (2005). Findings of recent IEA work, 2005, p72.
} 
energy consumption in $2005 .^{6}$ As China is now in the process of industrialization, the expansion of industrial production leads to rapid growth in energy consumption in both absolute and per capita terms. In 2004, China's total value added of industry (VAI) reached 5480.51 billion $\mathrm{RMB}$, with a $16.7 \%$ annual growth over the preceding period. The shares of heavy and light industry in total VAI were $67.6 \%$ and $32.5 \%$, respectively. According to a study by the National Development and Reform Commission (NDRC), China has come into the stage of heavy chemical industry era and the output of high energy consuming goods such as steel, cement, soda ash and caustic ash et al, increased dramatically in recent years (Table 3). ${ }^{7}$ Thus, the industrial sector with high energy intensity will be one of the major energy users in China. Second, the sectoral effect of energy import cannot be captured by employing GDP. For example, crude oil is imported largely as an industrial production input. Therefore, in view of the importance of the industrial sector in energy trade (i.e. oil imports), the value-added of industry (VAI) is chosen as one of the explanatory variables in the regression analysis. In addition, the impacts of heavy industry and light industry are also considered separately in the empirical exercises. Thus, the value-added of either heavy industry (VAHI) or light industry (VALI) is included in the analysis.

$$
\text { <insert Table } 3 \text { here }>
$$

\footnotetext{
${ }^{6}$ See footnote 2.

7 NDRC Energy Research Institute (ERI) (2004). The mid and long run trends of China's energy supply and demand and the strategy of sustainable development (wo guo neng yuan gong qiu zhong chang qi fa zhan qu shi ji ke chi xu fa zhan zhan lue), Econonics Study Reference (Jing ji yan jiu can kao), 92. 


\subsection{Total traffic volume}

Rapid expansion of the transport sector inevitably leads to a surge of demand for energy, especially for oil products. From 1990 to 2004, the number of passenger vehicles and civil aircrafts increased by about 9 and 1.5 times, respectively (Table 4). The total number of vehicles increased over ten millions since 2000 , over $80 \%$ of which is accounted by the growth of passenger vehicles. As for passenger traffic, vehicles and airplanes seem to be increasingly important in China, while the role of railways and waterways is declining (Table 5). With increasing income and development of the automotive industry in China, private cars are becoming affordable for more families. As a result, the number of privately owned vehicles increased from 2.5 million units in 1995 to 6.25 million units in 2000 and to 14.8 million units in 2004 (National Bureau of Statistics, 2005).

$$
\begin{aligned}
& <\text { insert Table } 4 \text { here }> \\
& <\text { insert Table } 5 \text { here }>
\end{aligned}
$$

The increase in travel by cars and airplanes creates great demand for oil products and this trend is likely to continue in the coming two decades as the process of industrialization in China advances. As demonstrated in Table 6, from 1990 to 2004, total volume of freight traffic increased 2.6 fold, with an average annual growth rate of 7.6\%. According to Skeer and Wang (2007), although the share of highways in total transport volume (passenger and freight) in 2000 was only $14 \%$, the share of its energy use was $68 \%$. The greater energy use in highway transport is due to rapid growth in highway traffic and the number of vehicles. Therefore, to capture the effects 
of the transport sector expansion on energy imports, total volumes of freight traffic (billion tone-km) as well as passenger traffic (billion passenger-km) are included in our empirical analysis.

$$
\text { <insert Table } 6 \text { here> }
$$

\section{Analytical framework}

To investigate the long run relationship between macroeconomic variables (i.e., crude oil, refined petroleum and liquefied petroleum gas) most of which are not stationary, cointegration technique and vector error correction model (VECM) are often employed as the main research tools. There are two reasons for choosing these two techniques. First, conventional econometric approaches such as OLS are subjected to spurious regression problems (Granger and Newbold 1974). Second, because most economic variables employed in the energy import demand equation such as output, price and value added of industry, are likely to be endogenous, estimating energy demand by a single equation may produce simultaneous bias and hence lead to unreliable results. Both problems can be overcome with the help of the vector error-correction model (VECM). In addition, a VEC model can capture the long-run relationship beween the economic variables and energy import demand.

To investigate whether there exist long-run cointegrating relationships among variables or not, two popular approaches are used in the literature, that is, the Engle-Granger (EG) procedure (1987) and the Johansen-Juselius (JJ) test (1990). In 
multivariate circumstances, the results of EG method are variant to the choice of variables selected for normalization, and can only produce one cointegrating vector. In addition, the EG procedure is implemented in two steps. Any error in the first step will be carried over into step two (Enders 2004). For these reasons, the JJ test is employed in this paper. It is based on the following vector auto-regression (VAR) model

$$
X_{t}=A_{0}+A_{1} X_{t-1}+A_{2} X_{t-2}+A_{3} X_{t-3}+\cdots+A_{p} X_{t-p}+u_{t}
$$

where $X_{t}$ is (n x 1) vector $\left(x_{1 t}, x_{2 t}, \cdots, x_{n t}\right)^{\prime}, A_{i}$ is (n x n) coefficients matrix of the lag term of $X_{t}, u_{t}$ is an independently and identically distributed (n x 1) vector with zero mean and variance matrix $\Omega, A_{0}$ is $(\mathrm{n} \times 1)$ vector of intercept terms. If the factors of $X_{t}$ are integrated with the same order, equation (1) can be rewritten in the following form

$$
\Delta X_{t}=A_{0}+\pi X_{t-p}+\sum_{i=1}^{p-1} \pi_{i} \Delta X_{t-i}+u_{t}
$$

where $\pi=\left(\sum_{i=1}^{p} A_{i}-I\right)$ and $\pi_{i}=\sum_{j=i+1}^{p} A_{j}-I$. The key feature of the JJ method is to examine the rank (r) of coefficient matrix $\pi$, which is equal to the number of independent cointegrating vectors. If $r=\operatorname{rank}(\pi)=0$, the matrix is null and equation (2) becomes the usual VAR in first differences; if $\mathrm{r}=\operatorname{rank}(\pi)=\mathrm{n}$, the vector process is stationary; and if $1<\mathrm{r}=\operatorname{rank}(\pi)<\mathrm{n}$, there are multiple cointegrating vectors. Then the matrix $\pi$ can be decomposed such that $\pi=\alpha \cdot \beta$, where $\alpha$ is a (n x r) matrix and $\beta=\left(\beta_{1}, \cdots, \beta_{r}\right)^{\prime}$ is a $(\mathrm{r} \times \mathrm{n})$ matrix, $\alpha$ is called the adjustment coefficient matrix and $\beta$ is called cointegrating matrix, each row of which is a cointegrating vector. To 
obtain the number of distinct cointegrating vectors, the JJ method introduced two statistics:

$$
\begin{aligned}
& \lambda_{\text {trace }}(r)=-T \sum_{i=r+1}^{n} \ln \left(1-\hat{\lambda}_{i}\right) \\
& \lambda_{\max }(r, r+1)=-T \ln \left(1-\hat{\lambda}_{i+1}\right)
\end{aligned}
$$

where $\hat{\lambda}_{i}$ is the estimated value of the characteristic roots (also called eigenvalues), and $\mathrm{T}$ is the number of observations. The first statistic, the trace test (also called the likelihood ratio test), tests the null hypothesis that there are at most $r$ cointegrating vectors against alternative cases of more than $r$ cointegrating vectors. The second statistic, known as the maximum eigenvalue test, tests the null hypothesis that the number of cointegrating vectors is $r$ against the alternative $r+1$. The critical values of these two statistics, $\lambda_{\text {trace }}$ and $\lambda_{\max }$, are obtained by Johansen and Juselius (1990) using the Monte Carlo simulation. If the above cointegration test suggests that there exists at least one cointegrating vector, the VECM can be expressed as

$$
\Delta X_{t}=A_{0}+\alpha \beta X_{t-p}+\sum_{i=1}^{p-1} \pi_{i} \Delta X_{t-i}+u_{t}
$$

In equation (5), the long-run equilibrium relationships between the variables are captured by the cointegrating term $\beta X_{t-p}$ and the error correction mechanism is reflected by the adjustment coefficient matrix $\alpha$. The coefficient matrix of the lagged first differences terms $\pi_{i}$, catches the short-run dynamics. To estimate the above described system of equations, several steps are followed. We first determine the order of integration of the variables by conducting the Augmented Dickey Fuller (ADF) test. If the variables are not stationary, we then conduct tests for cointegration 
among variables by applying the JJ approach. Finally, if the variables are cointegrated, an Error Correction Model (ECM) will be estimated to examine the long-run relationship between the variables. ${ }^{8}$ The specification of the models will be further discussed.

\section{Data and empirical results}

Since the original data used in this paper are monthly series, so we make the following adjustment before the modeling exercises. First, we convert the monthly series to quarterly series through arithmetical sum-up for variables in quantity terms (oil imports, domestic output, and total freight passenger traffic). For variables in value terms (crude oil price and industry value added), the monthly price indexes (1995:01=100) of industrial products are used to deflate the series before the conversion. ${ }^{9}$ Second, to remove the seasonal factors, we make seasonal adjustment for all variables through moving average before taking logarithms. Therefore, no seasonal dummies are included in our framework. All data but oil price are obtained from China economic information network (CEI) database. Table 7 lists the abbreviations for all the variables. Oil price data are obtained from International Financial Statistics (IMF).

$$
\text { <insert Table } 7 \text { here> }
$$

\footnotetext{
${ }^{8}$ It is noted that several other tests eg. the dynamic ordinary least squares (DOLS) and fully modified ordinary least squares (FMOLS) can also be used to test the existence of long-term relationship. Readers may refer to Philips and Hansen (1990), Stock and Watson (1993), Pesaran et al. (2001), and Narayan and Narayan (2005) for more details.

9 There are several reasons for converting monthly series to seasonal series. First, the frequency of the monthly data may be too short to capture the long run behavior of energy market, since changes of these macro-variables in aggregate terms cannot be seen as the long run trends. Second, strong cycling factors are included in the monthly data and will confuse our analysis of long-run relationship. Finally, the seasonal data are not available.
} 
The empirical work begins with the test of stationarity of the variables. The augmented Dickey-Fuller (ADF) tests are applied to all variables at level as well as their first difference series. The results are summarized in Table 8 . It can be seen that the null hypothesis of unit root cannot be rejected for the level of all variables at the $5 \%$ level of significance, while the first difference series seem to be stationary. Hence, we conclude that all variables are I(1).

$<$ insert Table 8 here $>$

To investigate the long-run relationship between different macro-variables (i.e., relative crude oil price, domestic energy output, industry value-added and total freight traffic) and energy imports (i.e., crude oil and petroleum products), we consider nine optional groupings as shown in Table 9 and construct VAR models for each group. Group 1 investigates the long-run relationship between oil imports and relative oil price, total energy output and total industry value added; groups 2 and 3 examine oil imports and value added of heavy and light industry, respectively; groups 4-7 investigate the relationship between China's output of each variety of primary energy goods (i.e., crude oil, coal, natural gas and hydroelectricity) and oil imports; and the last two groups, 8 and 9, examine the effects of freight traffic and passenger traffic on China's energy imports. The relative price of crude oil is included in all models as an important explanatory variable.

$<$ insert Table 9 here $>$

For each group, the JJ cointegration tests are conducted to identify whether there exist long-run relationships or cointegrating relationships among the variables. Since the 
results of the JJ cointegration tests are very sensitive to the lag length selected and assumption of the testing forms, we employ both Akaike's information criterion (AIC) and Schwarz information criterion (SIC) to choose the optimal lag length of the variables and include a constant term in the cointegrating equations. ${ }^{10}$

Another important issue is the specification of the VECM. That is whether or not the deterministic terms should enter the short-run and/or long-run model. In the estimation of vector error correction models for variables in each group, there are five cases for model configuration (Johansen, 1995): (1) There are no deterministic trends in the VAR and the cointegrating equations do not have intercepts; (2 )The VAR has no deterministic trends and the cointegrating equations have intercepts; (3) There are linear trends in the VAR but the cointegrating equations have only intercepts; (4) There are linear trends in both the VAR and the cointegrating equations; (5) The level data have quadratic trends and the cointegrating equations have linear trends. In practice, case 1 and case 5 are rarely used, because case 1 should only be used if all series have zero mean and case 5 may provide a good fit in-sample but will produce implausible forecasts out-of-sample (see the help file in Eviews 5.0). For the purpose of comparing the results from the nine groups, we specified the VECM of each group in a uniform manner in which the linear trends are shown in both VAR and the cointegration equations, ie. Case (4) as discussed above.

\footnotetext{
${ }^{10}$ The ADF tests also show that there are trends in most of the variables.
} 
The results of the JJ cointegration tests are reported in Table 10 which suggests that most groups have at least one cointegrating relationship among the variables. At the $5 \%$ level of significance, the hypothesis of none cointegration $(r=0)$ is rejected for all models except models (6) and (7). These findings suggest that there seems to exist long-run relationships between China's oil imports and the main macroeconomic variables, i.e., relative price of crude oil, domestic energy production, industry value-added (both heavy and light), whereas there is no cointegration relationship between oil imports and domestic natural gas or hydroelectricity output. Therefore, we construct the vector error correction procedures for all models except models (6) and (7). Since the aim of this study is to investigate the long-run determinants of energy imports in China, only the long-run equilibrium relationship extracted from the corresponding VECMs is reported and the full regression results of the VECMs are available upon request. The results are reported in Table 11. Several conclusions can be drawn.

$$
\begin{aligned}
& \text { <insert Table } 10 \text { here> } \\
& \text { <insert Table } 11 \text { here> }
\end{aligned}
$$

First, international relative price of oil seems not to be a major determinant of China's oil imports. In the long-run relationship reported in the table, the coefficients of relative oil price (Lnrpoilsa) are either significantly positive or not significant. In the models (1), (4) and (5), the sample ranges from 1995:Q1 to 2006:Q1, and the oil price variable shows a significantly positive relationship with imports, which implies that the price elasticity of crude oil is positive. This result is somewhat surprising as the 
classical economic theories tell us that demand and market price have a negative relationship. ${ }^{11}$ However, when other variables are introduced in models (2), (3), (8) and (9), the coefficient of relative price of oil is not statistically significant and its sign is not consistent. We hence argue that the international relative price of crude oil appears to have no stable long-run relationship with China's oil imports and it plays a trivial role in China's oil imports. This conclusion is consistent with the intuition from the reality. Even when international crude oil spot price (West Texas Intermediate) increased from US\$18.42 in 1995 to US\$41.49 per barrel in 2004, China's crude oil imports increased almost 8 times from 17.09 million tones to 122.72 million tones, with an average annual growth rate of $25 \% .^{12}$ In addition, most of China's oil imports are spot transactions such that China has little flexibility to respond to the constant fluctuation of international oil price. Moreover, the segmentation between domestic market and international market also weakened the function of price mechanism in the oil markets.

Second, the value added of the industrial sector shows a positive effect on oil imports. From the results reported in Table 11, the long run effects of total industry value-added on oil imports are significantly positive, as shown in models (1), (4) and (5). The same results can be obtained for both heavy and light industries as shown in models (2) and (3). The elasticity of oil imports on heavy and light industries is

\footnotetext{
11 The positive relationship between oil import and oil price may due to two reasons: (1) we miss some key explaining variables in the models; (2) the increase of oil price may be induced by China's strong import growth and therefore they exhibit a positive relation.

${ }^{12}$ BP (2005). BP statistical review of world energy, June, 2005, p14.
} 
greater than unity, which implies that oil imports would increase by $2.76 \%$ and $7.28 \%$ if the value-added of either heavy or light industry rise by $1 \%$. China's industrialization will be a driving force for energy consumption, and hence demand for energy imports.

Third, domestic energy production has a strong substitution effects on oil imports, especially for oil and coal outputs. The coefficients of total energy output in all models except (9) are significantly negative, although their magnitudes are different. This implies that the increase of China's total energy output is a substitute for oil imports and therefore reduces China's dependence on oversea oil sources. The failure of the cointegration tests to identify long-run relationships between oil imports and domestic natural gas or hydroelectricity reported in Table 10 suggests that the increase in natural and hydroelectricity output could not weaken oil imports. This result may be due to the fact that the shares of natural gas and hydroelectricity in total energy consumption are too small (about 10\% together) to affect oil imports. For domestic output of coal and oil, the substitution effects also exist in the long run, although the magnitude is different ( -9.49 for oil and -0.63 for coal). The coefficient of coal output is less than unity which suggests that coal has limit substitution effects for oil and the share of coal in total energy consumption is declining due to China's pro-clean energy policies.

Finally, the transport sector also plays an influential role in China's oil imports. As 
showed in models (8) and (9) reported in Table 11, the coefficients of total freight traffic and passenger traffic are 1.92 and 3.60, with both being statistically significant. Since all variables are in $\log$ forms, these two coefficients can be seen as the elasticity of oil import demand with respect to traffic volume. The results imply that rapid expansion of China's transport sector has contributed to the rise in oil imports. This conclusion is consistent with Skeer and Wang (2007) who argued that an increase in the transport sector activities will result in dramatic oil imports and hence push the world oil prices to increase in 2020.

\section{Conclusions and remarks}

Sustained economic growth in China has led to a surge of energy consumption and hence demand for energy imports. This paper analyzes the determinants of China's energy import demand (i.e., oil) by using cointegraiton and VECM techniques. It is found that international oil price is not a major determinant in China's oil imports. The unstable relationship between oil price and imports confirms that China is a "large country" in the international market and its trade behavior thus can influence the international price.

It is also shown that strong growth in industrial production is a key contributor to China's oil imports. Both heavy industry and light industry outputs are significant factors affecting oil imports. China's continued industrialization will result in continuous growth in energy imports in the coming decades. This study also 
demonstrates that domestic energy production, especially oil and coal outputs, has a strong substitution effect on oil imports. Finally, expansion of the transport sector also seems to play an influential role in China's oil imports. With increasing urbanization in China, considerable energy demand in the transport sector would further boost China's oil imports. This has implications for the global oil market as well as the Chinese economy.

Regardless of a price hike or not, China's demand for oil imports will rise. Though domestic production has an offsetting effect, its expansion is limited due to China's reserve constraints and increasing exploration costs. China's rising imports will add further pressure on world oil prices unless major oil producers take appropriate response measures. The increasing oil price will eventually raise the cost of goods produced in China which is nicknamed as the world factory. Such a scenario would be bad news for both China and the rest of the world. The rest of the world as the main consumer of Chinese manufactures will have to deal with price hikes and potentially high inflation which has been absent in the developed economies for many years. With increasing production costs, China's high economic growth would be in danger, a situation which is least wanted by China.

\section{References}

ABARE (2005). Australian energy, national and state projections to 2029-30. Australian Bureau of Agricultural and Resource Economics, Canberra. APERC (2002). APEC energy demand and supply outlook 2002. Asia Pacific Energy Research Centre, Tokyo. 
Australian Department of Foreign Affairs \& Trade (2006). Composition of trade Australia 2005.

Bernstein, M.A. and Griffin, J. (2005). Regional difference in the price elasticity of demand for energy, Rand Technical Report. Available from URL: http://www.rand.org/pubs/technical_reports/2005/RAND_TR292.sum.pdf.

BP (2005). Statistical review of world energy.

CEI (2005). China industrial annual report. Available from URL: http://www.ceiceo.cn/Exweb/2005report/ www/Column.asp?ColumnId=14.

Chan, H.L. and Lee, S.K. (1996). Forecasting the demand for energy in China, Energy Journal 17 (1), 19-30.

Chan, H.L. and Lee, S.K. (1997). Modelling and forecasting the demand for coal in China, Energy Economics 19, 271-87.

Crompton, P. and Wu, Y. (2005). Energy consumption in China: past trends and future directions, Energy Economics 27, 195-208.

Dahl, C.A. and Sterner, T. (1991). Analyzing gasoline demand elasticities: a survey, Energy Economics 13, 203-10.

DFAT (2005). Australia-China free trade agreement joint feasibility study, Department of Foreign Affairs and Trade, Canberra.

EIA (2005). China country analysis brief, United States of America. Available from URL: http://www.eia.doe.gov/emeu/cabs/China.html.

Enders, W. (2004). Applied Econometric Time Series, $2^{\text {nd }}$ edn. J. Wiley, New York.

Engle, R.F. and Granger, C.W.J. (1987). Cointegration and error correction: representation, estimation and testing, Econometrica 55 (2), 251-76.

ERI (2004). The mid and long run trends of China's energy supply and demand and the strategy of sustainable development (wo guo neng yuan gong qiu zhong chang qi fa zhan qu shi ji ke chi xu fa zhan zhan lue), Econonics Study Reference (Jing ji yan jiu can kao) (in Chinese), Energy Research Institute, National Development and Reform Commission.

Granger, C.W.J. and Newbold, P. (1974). Spurious regressions in econometrics, Journal of Econometrics 2, 111-20.

Han, W., Liu, X. and Zhu, X. (2000). Analysis on China's supply of and demand for oil and gas, Paper presented at Natural Gas Policy Seminar Beijing, June 2000.

Harris, R. (1995). Using Cointegration analysis in econometric modelling. Prentice Hall, Harvester Wheatsheaf, London.

Hirschhausen, C. and Andres, M. (2000). Long-term electricity demand in Chinafrom quantitative to qualitative grow? Energy Policy 28, 231-41.

IEA (2005). China's quest for energy security, in IEA (eds), Findings of recent IEA work 2005. International Energy Agency.

IEA (2005). Findings of recent IEA work 2005. International Energy Agency.

IMF (2006). International Financial Statistics, International Monetary Fund.

Jane Perlez (2006). Australia to sell uranium to China for energy, The New York Times, $3^{\text {rd }}$ April, 2006.

Jia, Q. and Zhong, T. (2005). Towards a mature relationship: China and Australia, in China in Australia's future. Growth, 55, p30-35. 
Johansen, S. (1992). Determination of cointegration rank in the presence of a linear trend, Oxford Bulletin of Economics and Statistics 54, 383-97.

Johansen, S. (1995). Likelihood-based inference in cointegrated vector autoregressive model. Oxford University Press.

Johansen, S. and Juselius, K. (1990). Maximum likelihood estimation and inferences on cointegration with approach, Oxford Bulletin of Economics and Statistics 52, 169-209.

Keii, C. (2000). China's energy supply and demand situations and coal industry's trends today, Research Reports, vol. 162. Institute of Energy Economics, Japan.

Lenegan, C., Beck, T. and Gray, M. (2005). Economic significance of resources and energy trade, in China in Australia's future, Growth 55, 36-47.

Li, Z. (2003). An econometric study on China's economy, energy and environment to the year 2030, Energy Policy 31, 1137-50.

Masih, A.M.M. and Masih, R.M. (1997). On the temporal causal relationship between energy consumption, Real Income, and prices: some new evidence from Asian-energy dependent NICs based on a multivariate cointegration/vector error-correction approach, Journal of Policy Modeling 19(4), 417-40.

Maxwell, D. (2004). Australia's role in China's growing energy market, an address to CEDA National Conference: The China story-resource \& beyond. Perth, August.

MOFCOM (2005). Country report-Australia, January. Available from URL: http://countryreport.mofcom.gov.cn/index.asp.

Narayan, Paresh Kumar and Narayan, Seema (2005), Estimating income and price elasticities of imports for Fiji in a cointegration framework, Economic Modelling 22, 423-43.

National Bureau of Statistics (2005). China statistical yearbook 2005, China Statistics Press, Beijing.

National Bureau of Statistics (2006). China statistical Abstract 2006, China Statistics Press, Beijing.

National Bureau of Statistics (various issues). China statistical yearbook, China Statistics Press, Beijing.

Osterwald-Lenum, M. (1992). A note with fractiles of the asymptotic distribution of the maximum likelihood cointegration rank test statistics: four cases, Oxford Bulletin of Economics and Statistics 54(3), 461-72.

Pesaran, M.H., Shin, Y. and Smith, R.J. (2001). Bounds testing approaches to the analysis of level relationships, Journal of Applied Econometrics 16, 289-326.

Phillips, P.C.B. and Hansen, B.E. (1990). Statistical inference in instrumental variable regression with I(1) processes, Review of Economic Studies 57, 99-125.

Skeer, J. and Wang, Y. (2006). Carbon charges and natural gas use in China, Energy Policy 34, 2251-62.

Skeer, J. and Wang, Y. (2007). China on move: Oil price explosion? Energy Policy 35, 678-91.

Stock, J.K. andWatson, M. (1993). A simple estimator of cointegrating vectors in higher order integrated systems, Econometrica 61, 783-820. 
Wei, W. (2002). Study on the determinants of energy demand in China, Journal of Systems Engineering and Electronics 13(3), 17-23.

Wolde-Rufael, Y. (2004). Disaggregated industrial energy consumption and GDP: the case of Shanghai, 1952-1999, Energy Economics 26, 69-75.

Wu, Y. (2003). Deregulation and growth in China's energy sector: a review of recent development, Energy Policy 31, 1417-25.

Xinhua News Agency (2006). China, Australia Sign Nuclear Energy Agreements, $4^{\text {th }}$ April 2006. Available from URL: http://english.China.com/zh cn/business/ energy/11025895/20060404/13219363.html.

Zhang, Z. (2003). Why did the energy intensity fall in China's industrial sector in 1990s? The relative importance of structural change and intensity change, Energy Economics 25, 625-38.

Zhou, F. (1999). Role of gas in China's energy economy and long-term forecast for natural gas demand, Paper presented at the Sino-IEA Conference on Natural Gas Industry, Beijing, November 9-10.

Zou, G. and Chau, K.W. (2006). Short- and Long-run effects between oil consumption and economic growth in China, Energy Policy 34, 3644-55. 


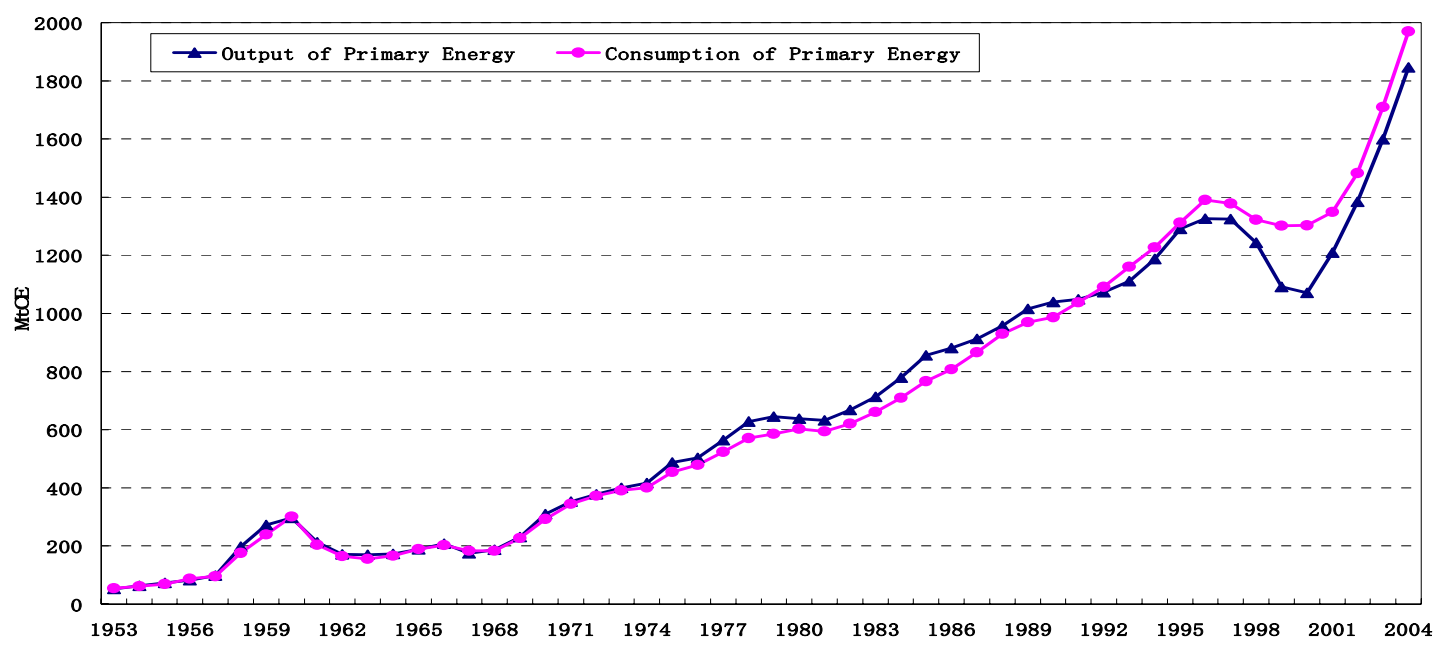

Source: CEI database.

Figure 1 Total primary energy output and consumption in China, 1953-2004.

Table 1 China total production of energy and its composition (1995-2004)

\begin{tabular}{cccccc}
\hline & Total Energy Production & \multicolumn{4}{c}{ As Per centage of Total Energy Production (\%) } \\
Year & $(10$ 000 tones of SCE $)$ & Coal & Crude Oil & Natural Gas & Hydro-power \\
\hline 1995 & 129034 & 75.3 & 16.6 & 1.9 & 6.2 \\
1996 & 132616 & 75.2 & 17.0 & 2.0 & 5.8 \\
1997 & 132410 & 74.1 & 17.3 & 2.1 & 6.5 \\
1998 & 124250 & 71.9 & 18.5 & 2.5 & 7.1 \\
1999 & 109126 & 68.3 & 21.0 & 3.1 & 7.6 \\
2000 & 106988 & 66.6 & 21.8 & 3.4 & 8.2 \\
2001 & 120900 & 68.6 & 19.4 & 3.3 & 8.7 \\
2002 & 138369 & 71.2 & 17.3 & 3.1 & 8.4 \\
2003 & 159912 & 74.5 & 15.1 & 2.9 & 7.5 \\
2004 & 184600 & 75.6 & 13.5 & 3.0 & 7.9 \\
\hline
\end{tabular}

Notes: Growth rate is from author's calculation.

Source: National Bureau of Statistics, 2005.

Table 2 China's production, consumption and trade of crude oil (1995-2004) (Million tones)

Annul growth rate

$(\%)$

\begin{tabular}{lcccccccr} 
Year & 1995 & 2000 & 2001 & 2002 & 2003 & 2004 & $95-04$ & \multicolumn{1}{c}{$00-04$} \\
\hline Production & 149.0 & 162.6 & 164.8 & 166.9 & 169.6 & 174.5 & 1.77 & 1.78 \\
Consumption & 160.7 & 230.1 & 232.2 & 246.9 & 266.4 & 308.6 & 7.52 & 7.61 \\
Import & 17.1 & 70.3 & 60.3 & 69.4 & 91.0 & 122.7 & 24.49 & 14.96 \\
Export & 48.85 & 10.31 & 7.55 & 7.21 & 8.13 & 5.49 & -21.56 & -14.58 \\
\hline
\end{tabular}

Notes: Growth rate is from author's calculation.

Source: BP Statistical review of world energy, June, 2005; State Custom Administration, P. R. China. 
Table 3 Outputs of some high energy intensity goods in China (1995-2004) (Million tones)

\begin{tabular}{|c|c|c|c|c|c|c|c|c|}
\hline \multirow[b]{2}{*}{ Products } & \multirow[t]{2}{*}{1995} & \multirow[t]{2}{*}{2000} & \multirow[t]{2}{*}{2001} & \multirow[t]{2}{*}{2002} & \multirow[t]{2}{*}{2003} & \multirow[t]{2}{*}{2004} & \multicolumn{2}{|c|}{$\begin{array}{c}\text { Average annual growth rate } \\
(\%)\end{array}$} \\
\hline & & & & & & & $1995-2000$ & 2000-04 \\
\hline Crude Steel & 95.36 & 128.50 & 151.63 & 182.37 & 222.34 & 272.80 & 6.15 & 20.71 \\
\hline Rolled Steel & 89.80 & 131.46 & 160.68 & 192.52 & 241.08 & 297.23 & 7.92 & 22.62 \\
\hline Cement & 475.61 & 597.00 & 661.04 & 725.00 & 862.08 & 970.00 & 4.65 & 12.90 \\
\hline Ethylene & 2.40 & 4.70 & 4.81 & 5.43 & 6.12 & 6.27 & 14.38 & 7.45 \\
\hline Soda Ash & 5.98 & 8.34 & 9.14 & 10.33 & 11.34 & 13.02 & 6.89 & 11.79 \\
\hline Caustic Soda & 5.32 & 6.68 & 7.88 & 8.78 & 9.45 & 10.60 & 4.66 & 12.25 \\
\hline
\end{tabular}

Notes: Growth rate is from author's calculation.

Source: National Bureau of Statistics, 2005.

Table 4 Number of civil Vehicles and civil aircrafts (1990-2004) (10000 units)

\begin{tabular}{lrrrrrrr}
\hline \multicolumn{1}{c}{ Year } & & & & & \multicolumn{2}{c}{ Absolute growth (units) } \\
\cline { 6 - 8 } & 1990 & 1995 & 2000 & 2004 & $90-95$ & $95-00$ & $00-04$ \\
\hline total vehicles & 551.36 & 1040.00 & 1608.91 & 2693.71 & 488.64 & 568.91 & 1084.80 \\
passenger vehicles & 162.19 & 417.90 & 853.73 & 1735.91 & 255.71 & 435.83 & 882.18 \\
trunks & 368.48 & 585.43 & 716.32 & 893.00 & 216.95 & 130.89 & 176.68 \\
civil aircrafts & 499.00 & 852.00 & 982.00 & 1245.00 & 353.00 & 130.00 & 263.00 \\
\hline
\end{tabular}

Notes: Growth is from author's calculation.

Source: National Bureau of Statistics, 2003, 2005.

Table 5 Composition of total passenger traffic (1990-2004) (billion passenger-km)

\begin{tabular}{lcccccc}
\hline & & & & \multicolumn{3}{c}{ Average annual growth (\%) } \\
Year & 1990 & 1995 & 2000 & 2004 & $1990-1995$ & $1995-2004$ \\
\hline Total & 562.8 & 900.2 & 1226.1 & 1630.9 & 9.85 & 6.83 \\
& $(100.0 \%)$ & $(100.0 \%)$ & $(100.0 \%)$ & $(100.0 \%)$ & & 5.44 \\
Railways & 261.3 & 354.6 & 453.3 & 571.2 & 6.30 & 7.40 \\
& $(46.4 \%)$ & $(39.4 \%)$ & $(37.0 \%)$ & $(35.0 \%)$ & & \\
Highways & 262.0 & 460.3 & 665.7 & 874.8 & 11.93 & -10.04 \\
& $(46.6 \%)$ & $(51.1 \%)$ & $(54.3 \%)$ & $(53.6 \%)$ & & \\
Waterways & 16.5 & 17.2 & 10.1 & 6.6 & 0.82 & 11.28 \\
& $(2.9 \%)$ & $(1.9 \%)$ & $(0.8 \%)$ & $(0.4 \%)$ & & 24.21 \\
Civil aviation & 23.0 & 68.1 & 97.1 & 178.2 & & \\
& $(4.1 \%)$ & $(7.6 \%)$ & $(7.9 \%)$ & $(10.9 \%)$ & & \\
\end{tabular}

Notes: the per centage shares are reported in the parenthesis and Growth rate is from author's calculation.

Source: National Bureau of Statistics, 2005. 
Table 6 Composition of total freight traffic (1990-2004) (billion tone-km)

\begin{tabular}{|c|c|c|c|c|c|c|}
\hline \multirow[b]{2}{*}{ Year } & \multirow[b]{2}{*}{1990} & \multirow[b]{2}{*}{1995} & \multirow[b]{2}{*}{2000} & \multirow[b]{2}{*}{2004} & \multicolumn{2}{|c|}{ Average annual growth $(\%)$} \\
\hline & & & & & 1990-1995 & 1995-2004 \\
\hline \multirow[t]{2}{*}{ Total } & 2620.7 & 3590.9 & 4432.1 & 6944.5 & 6.50 & 7.60 \\
\hline & $(100.0 \%)$ & $(100.0 \%)$ & $(100.0 \%)$ & $(100.0 \%)$ & & \\
\hline \multirow[t]{2}{*}{ Railways } & 1062.2 & 1305.0 & 1377.1 & 1928.9 & 4.20 & 4.44 \\
\hline & $(40.5 \%)$ & $(36.3 \%)$ & $(31.1 \%)$ & $(27.8 \%)$ & & \\
\hline \multirow[t]{2}{*}{ Highways } & 335.8 & 469.5 & 612.9 & 784.1 & 6.93 & 5.86 \\
\hline & $(12.8 \%)$ & $(13.1 \%)$ & $(13.8 \%)$ & $(11.3 \%)$ & & \\
\hline \multirow[t]{2}{*}{ Waterways } & 1159.2 & 1755.2 & 2373.4 & 4142.9 & 8.65 & 10.01 \\
\hline & $(44.2 \%)$ & $(48.9 \%)$ & $(53.6 \%)$ & $(59.7 \%)$ & & \\
\hline \multirow[t]{2}{*}{ Aviation } & 0.8 & 2.2 & 5.0 & 7.2 & 22.15 & 13.87 \\
\hline & $(0.0 \%)$ & $(0.1 \%)$ & $(0.1 \%)$ & $(0.1 \%)$ & & \\
\hline \multirow[t]{2}{*}{ Oil and Gas pipelines } & 62.7 & 59.0 & 63.6 & 81.5 & -1.21 & 3.65 \\
\hline & $(2.4 \%)$ & $(1.6 \%)$ & $(1.4 \%)$ & $(1.2 \%)$ & & \\
\hline
\end{tabular}

Notes: the per centage shares are reported in the parenthesis and growth rate is from author's calculation.

Source: National Bureau of Statistics, 2005.

Table 7 List of Variables

\begin{tabular}{lll}
\hline Variables & Details & Observations range \\
\hline Lncoimsa & Crude oil import & 1995Q1-2006Q1 \\
Lnrpoilsa & Relative price of crude oil & 1995Q1-2006Q1 \\
Lnvaisa & Value added of industry & 1995Q1-2006Q1 \\
Lnvahisa & Value added of heavy industry & 1998Q1-2006Q1 \\
Lnvalisa & Value added of light industry & 1998Q1-2006Q1 \\
Lnteopsa & Total domestic energy output & 1995Q1-2006Q1 \\
Lncoilopsa & Domestic crude oil output & 1995Q1-2006Q1 \\
Lncoalopsa & Domestic coal output & 1995Q1-2006Q1 \\
Lnngopsa & Domestic natural gas output & 1995Q1-2006Q1 \\
lnhyeopsa & Domestic hydroelectricity output & 1995Q1-2006Q1 \\
Lntvftsa & Total volume of freight traffic & 1998Q3-2006Q1 \\
Lntvptsa & Total volume of passenger traffic & 1998Q3-2006Q1 \\
\hline
\end{tabular}


Table 8 The results of ADF unit root tests (1995:Q1-2006:Q1)

\begin{tabular}{lcccc}
\hline & & Level series & \multicolumn{2}{c}{ First difference series } \\
Variables & With intercept & With intercept and trend & Without intercept & With intercept \\
\hline Lncoimsa & -1.94 & $-3.49 *$ & $-8.91^{* * *}$ & $-4.35^{* * *}$ \\
Lnrpoilsa & 0.39 & -2.76 & $-4.82^{* * *}$ & $-3.93^{* * *}$ \\
Lnvaisa & -0.77 & -2.08 & $-1.78^{*}$ & $-3.50^{* * *}$ \\
Lnvahisa & 1.44 & -1.92 & $-2.31^{* *}$ & $-5.50^{* * *}$ \\
Lnvalisa & 2.71 & -2.15 & $-3.41 * *$ & $-5.02^{* * *}$ \\
Lnteopsa & -1.25 & -0.04 & $-2.89 * *$ & $-3.14^{* *}$ \\
Lncoilopsa & 1.57 & -2.18 & $-7.75^{* * *}$ & $-9.16^{* * *}$ \\
Lncoalopsa & -1.91 & -0.27 & $-3.27 * * *$ & $-3.36^{* *}$ \\
Lnngopsa & 0.57 & -1.39 & $-5.02 * * *$ & $-6.26^{* * *}$ \\
lnhyeopsa & 2.23 & -1.68 & $-3.19^{* * *}$ & $-4.09^{* * *}$ \\
Lntvftsa & -0.76 & -2.89 & $-2.18^{* *}$ & $-4.09^{* * *}$ \\
Lntvptsa & -0.91 & -2.75 & $-7.17^{* * *}$ & $-7.55^{* * *}$ \\
\hline
\end{tabular}

Notes: a. ***,**, * means to reject the null hypothesis of a unit root at $1 \%, 5 \%$ and $10 \%$ critical value, respectively. The sample ranges of Lnvahisa and Lnvalisa are from 1998:Q1 through 2006:Q1; and Lntvftsa and Lntvptsa range from 1998:Q3 to 2006:Q1. b. the selection of the lags is based on the Akaike's information criterion (AIC) and Schwarz information criterion (SIC).

Table 9 Variables grouping

\begin{tabular}{clc}
\hline Group number & \multicolumn{1}{c}{ Variables } & Sample Range \\
\hline 1 & Lncoimsa, Lnrpoilsa, Lnteopsa, Lnvaisa & 1995Q1-2006Q1 \\
2 & Lncoimsa, Lnrpoilsa, Lnteopsa, Lnvahisa & 1995Q1-2006Q1 \\
3 & Lncoimsa, Lnrpoilsa, Lnteopsa,Lnvalisa & 1995Q1-2006Q1 \\
4 & Lncoimsa, Lnrpoilsa, Lncruoilopsa, Lnvaisa & 1995Q1-2006Q1 \\
5 & Lncoimsa, Lnrpoilsa, Lncoalopsa, Lnvaisa & 1995 Q1-2006Q1 \\
6 & Lncoimsa, Lnrpoilsa, Lnngopsa, Lnvaisa & $1995 Q 1-2006 Q 1$ \\
7 & Lncoimsa, Lnrpoilsa, Lnhyeopsa, Lnvaisa & $1995 Q 1-2006 Q 1$ \\
8 & Lncoimsa, Lnrpoilsa, Lnteopsa, Lntvftsa & $1998 Q 3-2006 Q 1$ \\
9 & Lncoimsa, Lnrpoilsa, Lnteopsa, Lntvptsa & 1998Q3-2006Q1 \\
\hline
\end{tabular}


Table 10 Results of Johansen \& Juliusen Cointegration Test

\begin{tabular}{|c|c|c|c|c|c|c|c|c|c|c|c|}
\hline \multirow[b]{2}{*}{ VAR $^{a}$} & \multirow[b]{2}{*}{$\mathrm{Lag}^{\mathrm{b}}$} & \multicolumn{5}{|c|}{ Trace test } & \multicolumn{5}{|c|}{ Maximum eigenvalues test } \\
\hline & & $\mathrm{H}_{0}$ & $\mathrm{H}_{1}$ & $\begin{array}{c}\text { Trace } \\
\text { Statistic } \lambda_{\text {trace }}\end{array}$ & $\begin{array}{c}\% \\
\text { critical } \\
\text { value }^{\mathrm{c}}\end{array}$ & Prob. & $\mathrm{H}_{0}$ & $\mathrm{H}_{1}$ & $\begin{array}{c}\text { Max-Eigen } \\
\text { Statistic } \lambda_{\max }\end{array}$ & $\begin{array}{c}5 \% \\
\text { critical } \\
\text { value }^{\mathrm{c}}\end{array}$ & Prob. \\
\hline \multirow[t]{3}{*}{ (1) } & 4 & $\mathrm{r}=0$ & $\mathrm{r}=1$ & $65.175 * * *$ & 47.856 & 0.001 & $\mathrm{r}=0$ & $\mathrm{r} \geq 1$ & $40.077 * * *$ & 27.584 & 0.001 \\
\hline & & $\mathrm{r} \leq 1$ & $\mathrm{r}=2$ & 25.098 & 29.797 & 0.158 & $\mathrm{r}=1$ & $\mathrm{r} \geq 2$ & 16.260 & 21.132 & 0.210 \\
\hline & & $\mathrm{r} \leq 2$ & $\mathrm{r}=3$ & 8.838 & 15.495 & 0.381 & $\mathrm{r}=2$ & $r \geq 3$ & 5.869 & 14.265 & 0.630 \\
\hline \multirow[t]{3}{*}{ (2) } & 2 & $\mathrm{r}=0$ & $\mathrm{r}=1$ & $63.980 * * *$ & 47.856 & 0.001 & $\mathrm{r}=0$ & $\mathrm{r} \geq 1$ & $31.135^{* *}$ & 27.584 & 0.017 \\
\hline & & $\mathrm{r} \leq 1$ & $\mathrm{r}=2$ & $32.845^{* *}$ & 29.797 & 0.022 & $\mathrm{r}=1$ & $\mathrm{r} \geq 2$ & $18.970 *$ & 21.132 & 0.098 \\
\hline & & $\mathrm{r} \leq 2$ & $r=3$ & $13.875^{*}$ & 15.495 & 0.086 & $\mathrm{r}=2$ & $r \geq 3$ & $13.454^{*}$ & 14.265 & 0.067 \\
\hline \multirow[t]{3}{*}{ (3) } & 2 & $\mathrm{r}=0$ & $\mathrm{r}=1$ & $58.186 * * *$ & 47.856 & 0.004 & $\mathrm{r}=0$ & $\mathrm{r} \geq 1$ & $30.687 * * *$ & 27.584 & 0.019 \\
\hline & & $\mathrm{r} \leq 1$ & $\mathrm{r}=2$ & $27.500 *$ & 29.797 & 0.090 & $\mathrm{r}=1$ & $\mathrm{r} \geq 2$ & 15.539 & 21.132 & 0.253 \\
\hline & & $\mathrm{r} \leq 2$ & $r=3$ & 11.961 & 15.495 & 0.159 & $\mathrm{r}=2$ & $r \geq 3$ & 11.819 & 14.265 & 0.118 \\
\hline \multirow[t]{3}{*}{ (4) } & 1 & $\mathrm{r}=0$ & $\mathrm{r}=1$ & $64.153^{* * *}$ & 47.856 & 0.001 & $\mathrm{r}=0$ & $\mathrm{r} \geq 1$ & $36.719 * * *$ & 27.584 & 0.003 \\
\hline & & $\mathrm{r} \leq 1$ & $\mathrm{r}=2$ & $27.434^{*}$ & 29.797 & 0.092 & $\mathrm{r}=1$ & $\mathrm{r} \geq 2$ & 12.882 & 21.132 & 0.463 \\
\hline & & $\mathrm{r} \leq 2$ & $\mathrm{r}=3$ & $14.552 *$ & 15.495 & 0.069 & $\mathrm{r}=2$ & $r \geq 3$ & 10.136 & 14.265 & 0.203 \\
\hline \multirow[t]{3}{*}{ (5) } & 4 & $\mathrm{r}=0$ & $\mathrm{r}=1$ & $66.664 * * *$ & 47.856 & 0.000 & $\mathrm{r}=0$ & $\mathrm{r} \geq 1$ & $42.381 * * *$ & 27.584 & 0.000 \\
\hline & & $\mathrm{r} \leq 1$ & $\mathrm{r}=2$ & 24.283 & 29.797 & 0.189 & $\mathrm{r}=1$ & $\mathrm{r} \geq 2$ & 16.260 & 21.132 & 0.210 \\
\hline & & $\mathrm{r} \leq 2$ & $r=3$ & 8.023 & 15.495 & 0.463 & $\mathrm{r}=2$ & $r \geq 3$ & 5.096 & 14.265 & 0.730 \\
\hline \multirow[t]{3}{*}{ (6) } & 2 & $\mathrm{r}=0$ & $\mathrm{r}=1$ & 42.006 & 47.856 & 0.159 & $\mathrm{r}=0$ & $\mathrm{r} \geq 1$ & 17.968 & 27.584 & 0.498 \\
\hline & & $\mathrm{r} \leq 1$ & $\mathrm{r}=2$ & 24.038 & 29.797 & 0.199 & $\mathrm{r}=1$ & $\mathrm{r} \geq 2$ & 11.955 & 21.132 & 0.552 \\
\hline & & $r \leq 2$ & $\mathrm{r}=3$ & 12.083 & 15.495 & 0.153 & $\mathrm{r}=2$ & $r \geq 3$ & 9.681 & 14.265 & 0.234 \\
\hline \multirow[t]{3}{*}{ (7) } & 1 & $\mathrm{r}=0$ & $\mathrm{r}=1$ & $50.759 * *$ & 47.856 & 0.026 & $\mathrm{r}=0$ & $\mathrm{r} \geq 1$ & 24.396 & 27.584 & 0.122 \\
\hline & & $\mathrm{r} \leq 1$ & $\mathrm{r}=2$ & 26.363 & 29.797 & 0.118 & $\mathrm{r}=1$ & $\mathrm{r} \geq 2$ & 15.056 & 21.132 & 0.285 \\
\hline & & $\mathrm{r} \leq 2$ & $r=3$ & 11.307 & 15.495 & 0.193 & $\mathrm{r}=2$ & $r \geq 3$ & 9.110 & 14.265 & 0.277 \\
\hline \multirow[t]{3}{*}{ (8) } & 4 & $\mathrm{r}=0$ & $\mathrm{r}=1$ & $77.205^{* * *}$ & 47.856 & 0.000 & $\mathrm{r}=0$ & $\mathrm{r} \geq 1$ & $51.320 * * *$ & 27.584 & 0.000 \\
\hline & & $\mathrm{r} \leq 1$ & $\mathrm{r}=2$ & 25.885 & 29.797 & 0.132 & $\mathrm{r}=1$ & $\mathrm{r} \geq 2$ & 15.450 & 21.132 & 0.259 \\
\hline & & $\mathrm{r} \leq 2$ & $\mathrm{r}=3$ & 10.436 & 15.495 & 0.249 & $\mathrm{r}=2$ & $\mathrm{r} \geq 3$ & 10.382 & 14.265 & 0.188 \\
\hline \multirow[t]{3}{*}{ (9) } & 2 & $\mathrm{r}=0$ & $\mathrm{r}=1$ & $67.583 * * *$ & 47.856 & 0.000 & $\mathrm{r}=0$ & $\mathrm{r} \geq 1$ & $37.826 * * *$ & 27.584 & 0.002 \\
\hline & & $\mathrm{r} \leq 1$ & $\mathrm{r}=2$ & $29.757^{*}$ & 29.797 & 0.051 & $\mathrm{r}=1$ & $\mathrm{r} \geq 2$ & 15.719 & 21.132 & 0.242 \\
\hline & & $\mathrm{r} \leq 2$ & $\mathrm{r}=3$ & $14.039 *$ & 15.495 & 0.082 & $r=2$ & $r \geq 3$ & $13.350 *$ & 14.265 & 0.069 \\
\hline
\end{tabular}

Notes: The vector autoregression (VAR) models (1)-(9) are corresponding to the 9 groups listed in Table 9 and $r$ represents the number of cointegrating vectors. The lag length in each model is identified by both Akaike's information criterion (AIC) and Schwarz information criterion (SIC). The critical values are drawn from Osterwald-Lenum (1992). ***,** and * indicate significance at the level of $1 \%$, $5 \%$ and $10 \%$, respectively. 
Table 11 Long-run equilibrium relationship from VCEMs

\begin{tabular}{|c|c|c|c|c|c|c|c|}
\hline $\begin{array}{l}\text { Dependent } \\
\text { variables }\end{array}$ & & & & Lncoimsa & & & \\
\hline \multirow{2}{*}{ Models } & (1) & (2) & (3) & (4) & (5) & (8) & (9) \\
\hline & 95Q1-06Q1 & 98Q1-06Q1 & 98Q1-06Q1 & 95Q1-06Q1 & 95Q1-06Q1 & 98Q3-06Q1 & 98Q3-06Q1 \\
\hline $\mathrm{C}$ & 12.43 & 32.73 & 65.61 & 80.43 & 9.56 & -2.19 & -15.53 \\
\hline \multirow[t]{2}{*}{ Lnrpoilsa } & $0.58 * * *$ & 0.17 & -0.37 & $0.81 * * *$ & $0.51 * * *$ & 0.19 & -0.38 \\
\hline & $(3.36)$ & $(1.07)$ & $(-1.14)$ & $(2.72)$ & (3.13) & $(1.00)$ & $(-1.20)$ \\
\hline \multirow[t]{2}{*}{ Lnvaisa } & $1.01 * * *$ & & & $1.23 * * *$ & $0.89 * * *$ & & \\
\hline & $(4.35)$ & & & $(2.93)$ & $(4.26)$ & & \\
\hline \multirow[t]{2}{*}{ Lnvahisa } & & $2.76^{* * *}$ & & & & & \\
\hline & & $(7.55)$ & & & & & \\
\hline \multirow[t]{2}{*}{ Lnvalisa } & & & $7.28 * * *$ & & & & \\
\hline & & & (6.37) & & & & \\
\hline \multirow[t]{2}{*}{ Lnteopsa } & $-0.96 * * *$ & $-3.49 * * *$ & $-8.08 * * *$ & & & $-0.83 * * *$ & -0.57 \\
\hline & $(-4.64)$ & $(-6.49)$ & $(-6.05)$ & & & -3.70 & $(-1.52)$ \\
\hline \multirow[t]{2}{*}{ Lncoilopsa } & & & & $-9.49 * * *$ & & & \\
\hline & & & & $(-3.01)$ & & & \\
\hline \multirow[t]{2}{*}{ Lncoalopsa } & & & & & $-0.63 * * *$ & & \\
\hline & & & & & $(-5.21)$ & & \\
\hline \multirow[t]{2}{*}{ Lntvftsa } & & & & & & $1.92 * * *$ & \\
\hline & & & & & & $(4.92)$ & \\
\hline \multirow[t]{2}{*}{ Lntvptsa } & & & & & & & $3.60 * * *$ \\
\hline & & & & & & & (6.64) \\
\hline
\end{tabular}

Notes: The long run cointegration relationship reported in this table is extracted from each of the vector error correction models (VECMs). The subscripts ( $\mathrm{t}-1$ ) for all variables are dropped. The t-statistics are reported in the parenthesis. $* * *, * *$ and $*$ indicate significance at the level of $1 \%, 5 \%$ and $10 \%$, respectively. 